\title{
Spontaneous extensive spinal epidural abscess presenting as acute quadriparesis
}

\author{
Rajesh Verma, Tejendra S Chaudhari, Gaurav Lachuriya
}

Department of Neurology, King George's Medical University, Lucknow, Uttar Pradesh, India

\section{Correspondence to} Professor Rajesh Verma, drrajeshverma32@yahoo.com

Accepted 21 November 2014

\section{DESCRIPTION}

An extensive spinal epidural abscess (SEA), sometimes referred to as a panspinal or holocord SEA, is a rare neurosurgical emergency. We present an interesting case of spontaneous extensive SEA that was managed with multilevel laminectomy along with intravenous antibiotics.

A 35-year-old-man presented with high-grade fever and excruciating backache of 20 days duration, quadriparesis for 3 days and respiratory distress a day before admission. Quadriparesis evolved symmetrically over $24 \mathrm{~h}$, initially affecting the lower extremities followed by upper extremities within few hours. There was no history of diabetes, trauma, intravenous drug abuse or any other medical comorbidity. On examination, his vital parameters were stable except for tachycardia and tachypnoea. Neurological examination revealed sensory motor quadriparesis with C4 sensory level and extensor plantar response. Power was grade 0 in the lower limbs and grades $1-2$ in the upper limbs. Routine blood investigations were normal and did not reveal any comorbid disorder. HIV ELISA was negative. MRI of the spine revealed extensive epidural collection from C4 to L5 vertebral levels along with hyperintensity and cord enlargement in the cervical region from $\mathrm{C} 4$ to $\mathrm{C} 7$ on T2-weighted image (figure $1 \mathrm{~A}-\mathrm{F}$ ). Urgent neurosurgical intervention in the form of multiple level laminectomy from C7 to T8 levels and in the lumbar region was performed. Examination of drained pus revealed coagulase-negative staphylococci. The patient was treated with intravenous antibiotics for 4 weeks. At 6-week follow-up, there were no constitutional symptoms and power improved from grades 0 to 3 .

An extensive SEA is rare and usually occurs in immunocompromised hosts, patients with disruption of the spinal column, diabetes or in the presence of septic focus. ${ }^{12}$ Our patient lacked any such risk factors. Hence, we labelled it as spontaneous SEA. Such spontaneous extensive SEAs have been
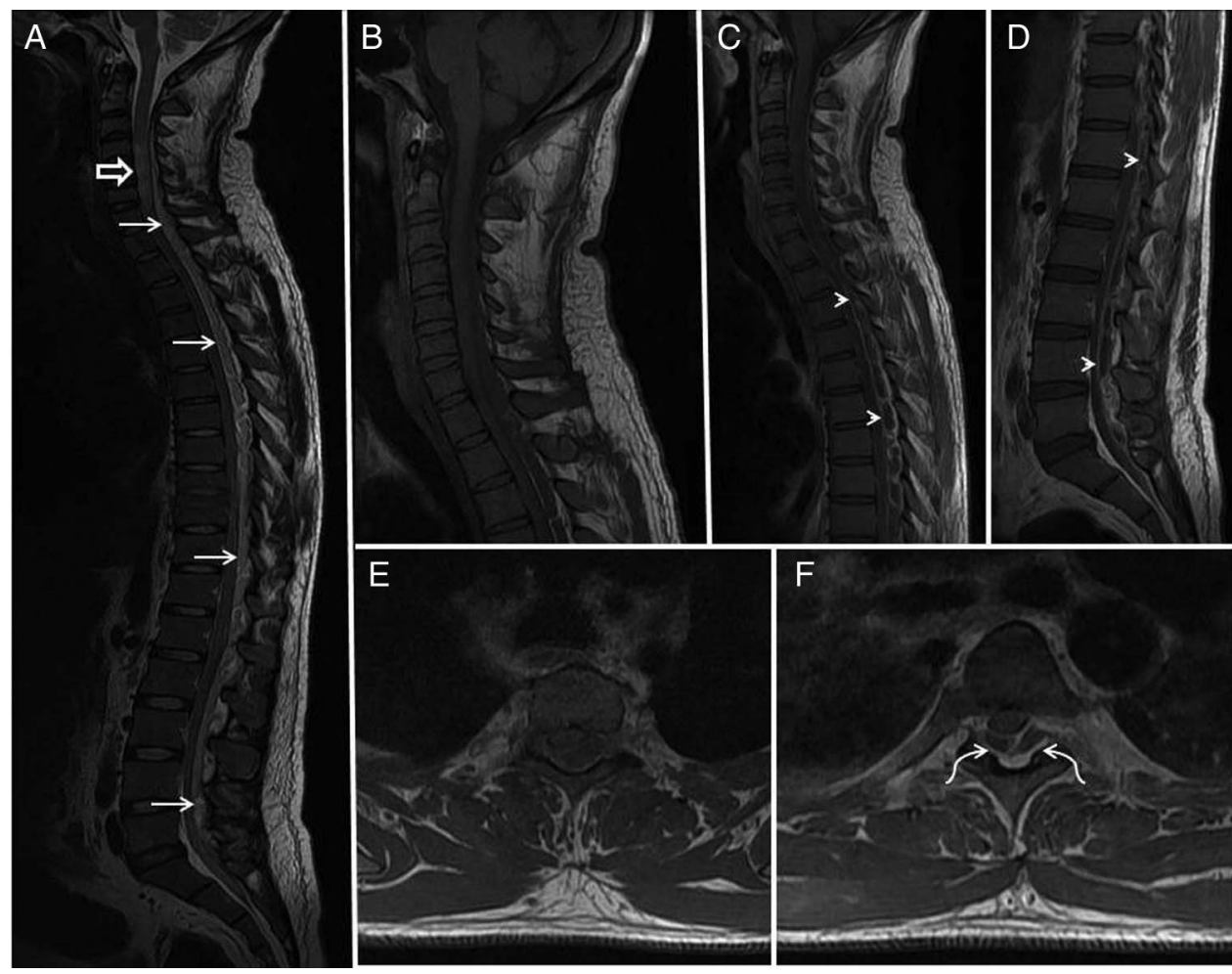

Figure 1 MRI of the spine: (A) sagittal T2-weighted (T2W) image of the whole spine showing extensive epidural

To cite: Verma $R$, Chaudhari TS, Lachuriya G. BMJ Case Rep Published online: [please include Day Month Year] doi:10.1136/ bcr-2014-204892 collection from C4 to L5 level (solid white arrows). It also shows hyperintensity in the cord from C4 to C7 level along with cord enlargement s/o myelitis (hollow white arrow). (B) Sagittal T1W, (C) postcontrast T1W (cervicothoracic region) and (D) postcontrast T1W (lumbosacral region) images showing extensive epidural collection with postcontrast enhancement in the cervicothoracic and lumbar region, respectively (arrow heads). (E) Axial T1W and (F) axial postcontrast images (at T2 vertebral level) reveal epidural collection with postcontrast enhancement (curved arrows) causing displacement and compression of the cord. 
described previously in the literature. ${ }^{1}$ It is a neurosurgical emergency; prompt diagnosis and urgent decompression of the spinal canal along with intravenous antibiotics results in good recovery.

\section{Learning points}

- An extensive spinal epidural abscess (SEA) is a lethal neurosurgical emergency.

- The best clinical outcome depends on early intervention.

- The acute presentation of quadriparesis should raise suspicion of SEA, even in the absence of predisposing factors.
Contributors RV conceptualised the idea and TSC and GL helped in preparing the manuscript.

Competing interests None.

Patient consent Obtained.

Provenance and peer review Not commissioned; externally peer reviewed.

\section{REFERENCES}

1 Purkayastha S. Spontaneous extensive spinal epidural abscess without any identifiable risk factor. A case report. Neuroradiol J 2008;21:371-3.

2 Tahir MZ, Hassan RU, Enam SA. Management of an extensive spinal epidural abscess from C-1 to the sacrum. Case report. J Neurosurg Spine 2010;13:780-3.

Copyright 2014 BMJ Publishing Group. All rights reserved. For permission to reuse any of this content visit

http://group.bmj.com/group/rights-licensing/permissions.

BMJ Case Report Fellows may re-use this article for personal use and teaching without any further permission.

Become a Fellow of BMJ Case Reports today and you can:

- Submit as many cases as you like

- Enjoy fast sympathetic peer review and rapid publication of accepted articles

- Access all the published articles

- Re-use any of the published material for personal use and teaching without further permission

For information on Institutional Fellowships contact consortiasales@bmjgroup.com

Visit casereports.bmj.com for more articles like this and to become a Fellow 